by M. H. Henriques ${ }^{1,2}$, M. L. Canales $^{3}$, S. C. Silva ${ }^{l}$ and V. Figueiredo ${ }^{l}$

\title{
Integrated biostratigraphy (Ammonoidea, Foraminiferida) of the Aalenian of the Lusitanian Basin (Portugal): A synthesis
}

\footnotetext{
${ }^{1}$ Geosciences Centre and Department of Earth Sciences, University of Coimbra (Polo II), Rua Sílvio Lima, 3030-790 Coimbra, Portugal. E-mail: hhenriq@dct.uc.pt; silviaclara55@gmail.com;verfigueiredo@gmail.com

${ }^{2}$ Convenor of the Aalenian Working Group of the International Subcommission on Jurassic Stratigraphy

${ }^{3}$ Department of Paleontology, Faculty of Geological Sciences, University Complutense of Madrid; c/José Antonio Novais, 12, 28040 Madrid, Spain.E-mail:mcanales@geo.ucm.es
}

(Received $14^{\text {th }}$ July 2015; Accepted $12^{\text {th }}$ February, 2016)

DOI:10.18814/epiiugs/2016/v39i3/99742

This work reports a synthesis of biostratigraphic outputs resulting from over two decades of comprehensive analysis on the expressive stratigraphic record of the Aalenian of the Lusitanian Basin (Western Iberian Margin; Portugal). The rich and diverse ammonite record studied from ten marly and marlylimestones sections, outcropping in different sectors of the basin ranging from distal to proximal facies, has enabled the establishment of a detailed ammonite-based biostratigraphical framework correlated with other basins located around the Iberian Plate. The study of the benthic foraminiferal assemblages occurring in the basin at the same time interval has allowed the establishment of a biostratigraphic scale based on microfossils accurately calibrated with the ammonite record, an important tool in log interpretation in the context of hydrocarbon exploration activities in sedimentary basins of Jurassic age.

The corresponding biostratigraphic units are characterized, as well as the bioevents recognized in the benthic foraminiferal record, which represent another additional proxy of local and/or regional rank that can be used to determine both the age and depositional environment assigned to core samples.

\section{Introduction}

The accurate biostratigraphy of the Aalenian of the Lusitanian Basin (Portugal) based on the rich and diverse ammonite record is known in detail since 1992 for the northern sector of the basin (Henriques, 1992, 1995) and since 2000 for the central sector of the basin (Henriques, 2000).
The study of ten fossiliferous sections located in different depositional contexts along the Lusitanian Basin, ranging from distal to proximal positions within the basin, has enabled the establishment of a biostratigraphical framework correlated with other basins located around the Iberian Plate, namely in the Basque-Cantabrian, Iberian and Betic Cordilleras (Henriques et al., 1996; Sandoval et al., 2000, 2001; Henriques et al., 2014).

Ammonites are the best fossil group for dating Jurassic marine sediments, and support most of the standard zones established for the Jurassic period. However, alternative biostratigraphic scales based on other fossil groups are needed when ammonites are poorly preserved, scarce or almost impossible to obtain (e.g., in core samples). Since 2008, detailed sampling on the Aalenian sections of the Lusitanian Basin for foraminiferal studies has been carried out, based on previous biostratigraphic data provided by the ammonoid record (Henriques, 1992, 1995, 2000), and following the same methodological procedures (see Canales and Henriques, 2008). The obtained biostratigraphic results enabled the establishment of a biozonal framework for the Upper Toarcian - Lower Bajocian (Lower - Middle Jurassic) interval of the Lusitanian Basin based on foraminifera and accurately calibrated with the ammonite record.

This work aims at presenting a synthesis of the biostratigraphical framework of the Aalenian of the Lusitanian Basin based on the cooccurrence of ammonoid and benthic foraminiferal assemblages as a result of over two decades of detailed sampling and consistent data treatment of abundant material collected from coeval, continuous and not condensed sections representing that time interval. The corresponding biostratigraphic units, represented by ammonite-based assemblage biozones and foraminiferal-based interval biozones (Murphy and Salvador, 1999) are characterized, thus contributing to a better calibration of the biostratigraphic scale for the Aalenian on the basis of macro- and microfossil groups, an important tool in log interpretation in the context of hydrocarbon exploration activities in Jurassic sedimentary basins. Bioevents recognized in the benthic foraminiferal record represent an additional proxy of local and/or regional rank that can be used to determinate both the age and 
depositional environment assigned to core samples (Canales et al., 2010).

\section{Geographical location and geological setting}

The Lusitanian Basin (Central Portugal) is a marginal basin located at the Western Iberian Margin representing the inner and most proximal margin of much larger basins extending towards the shallow and deep offshore: the Porto and Galicia basins in Northern Iberia, the Peniche and Alentejo basins in Southwestern Iberia and the Algarve Basin in Southern Iberia (Pena dos Reis and Pimentel, 2014) (Fig. 1). The genesis and evolution of the Lusitanian Basin is related to the opening of the North and Central Atlantic Ocean, but effects of the Western Tethys geodynamics can also be recognized (Azerêdo et al., 2003), in particular as regards the biotic components of its sedimentary infill.

The Aalenian is very well represented in the onshore sector of the Lusitanian Basin, with very fossiliferous marly and marly-limestone successions showing an increasing NW-SE differentiation within a carbonate platform, which corresponds to the sag interval that followed the Late Triassic rifting episode and preceded the Late Jurassic rifting event (Pena dos Reis and Pimentel, 2010, 2014; Pimentel et al., 2010).

The resulting distal, middle and proximal facies of this marine depositional system correspond to the lithostratigraphic units represented in Fig. 2, to which the sections of the material studied in this work are referred (Fig. 3):

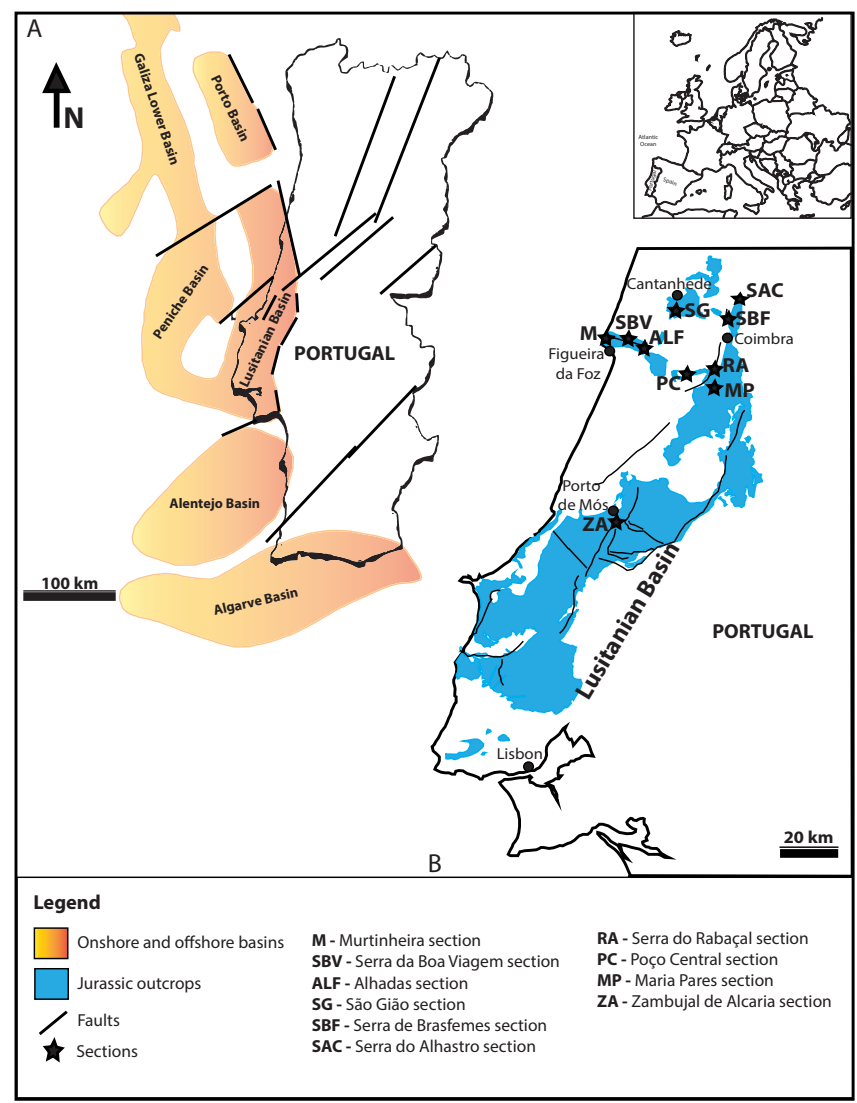

Figure 1. A. Location of the onshore and offshore basins of the Western Iberian Margin (modified after Pena dos Reis and Pimentel, 2014). B. Jurassic record of the onshore of the Lusitanian Basin (in blue) indicating the location of the studied sections.
- in the Northern Lusitanian Basin, in the Figueira da Foz region: the Murtinheira section, where the Bajocian GSSP has been established (Pavia and Enay, 1997), the Serra da Boa Viagem I section (Henriques, 1992), the Serra da Boa Viagem II section (Canales and Henriques, 2008, 2013; Silva et al., 2014, 2015b) and the Alhadas section (Henriques, 1992). The Aalenian record, which integrates the Cabo Mondego Formation, attains a thickness of about $80 \mathrm{~m}$ and is composed of rhythmic alternations of dark greyish marly-limestone and marls, with abundant planktonic, nektonic and benthonic fossils, corresponding to distal positions within the basin (Azerêdo et al., 2003; Canales et al., 2014);

- in the Northern Lusitanian Basin, in the Cantanhede-Coimbra region: the São Gião section (Henriques and Canales, 2013), the Serra de Brasfemes section, the Serra do Alhastro section, the Serra do Rabaçal section, the Poço Central (North and South) sections (Henriques, 1992) and the Maria Pares section (Figueiredo and Guterres, 2012; Figueiredo et al., 2014). The Aalenian record is about $50 \mathrm{~m}$ thick, but at least its lower part shows significant lateral variations in thickness, whereas its upper part shows an upward increase in limestone content, thus foreshadowing the retraction of the outer facies to the N/NW of the basin, which becomes more evident in the Bajocian (Azerêdo et al., 2003 and references therein). They integrate the Póvoa da Lomba Formation which is composed of greyish marlylimestones, alternating with slightly thicker greyish marl beds organized in shallowing-upward units, and it is interpreted as representing the middle paleogeographic position of the platform (Azerêdo et al., 2003; Canales et al., 2014);

- in the Central Lusitanian Basin, near Fátima: the Zambujal de Alcaria section (Henriques, 2000; Figueiredo et al., 2010, 2014), where the Aalenian record is about $60 \mathrm{~m}$ thick. It includes the upper part of the Fórnea Formation, composed of rhythmic alternations of greyish marly-limestone and marls, and the lower part of the Barranco de Zambujal Formation, composed of whitish marly-limestone with an upward increase in limestone content and thickness. It represents the most proximal paleogeographic position within the basin (Azerêdo et al., 2003; Canales et al., 2014).

\section{Ammonite-based biostratigraphic units}

The ammonite record of the Aalenian of the Lusitanian Basin includes typical Northwestern European taxa (Leioceratinae, Graphoceratinae) together with typical Mediterranean ones (Grammoceratinae, Tmetoceratinae, Erycitidae, Hammatoceratinae). No Tethysian phylloceratids were found and drift adult shells of Lytoceratina appear sporadically in proximal facies and more persistently in distal facies. The preservation features of the ammonite assemblages, described in detail by Fernández López et al. (1999a, b) and Henriques and Canales (2013), support the demic nature of the fossil assemblages, which are mainly composed by resedimented elements. Taxonomic studies and paleogeographic implications of this group can be found in Henriques (1992, 1995, 2000), FernándezLópez et al. (1999a, b) and Sandoval et al. (2012). They result from long-term sampling on ten different sections, which provided more than 3,000 ammonite specimens, all stored at the Laboratory of Sedimentary Geology and Fossil Record of the Department of Earth Sciences at the University of Coimbra (Portugal). 
W(NW)

C. Mondego Cantanhede Coimbra Sicó Tomar Maciço Calcário Estremenho Montejunto Arrábida Sto. Cacém

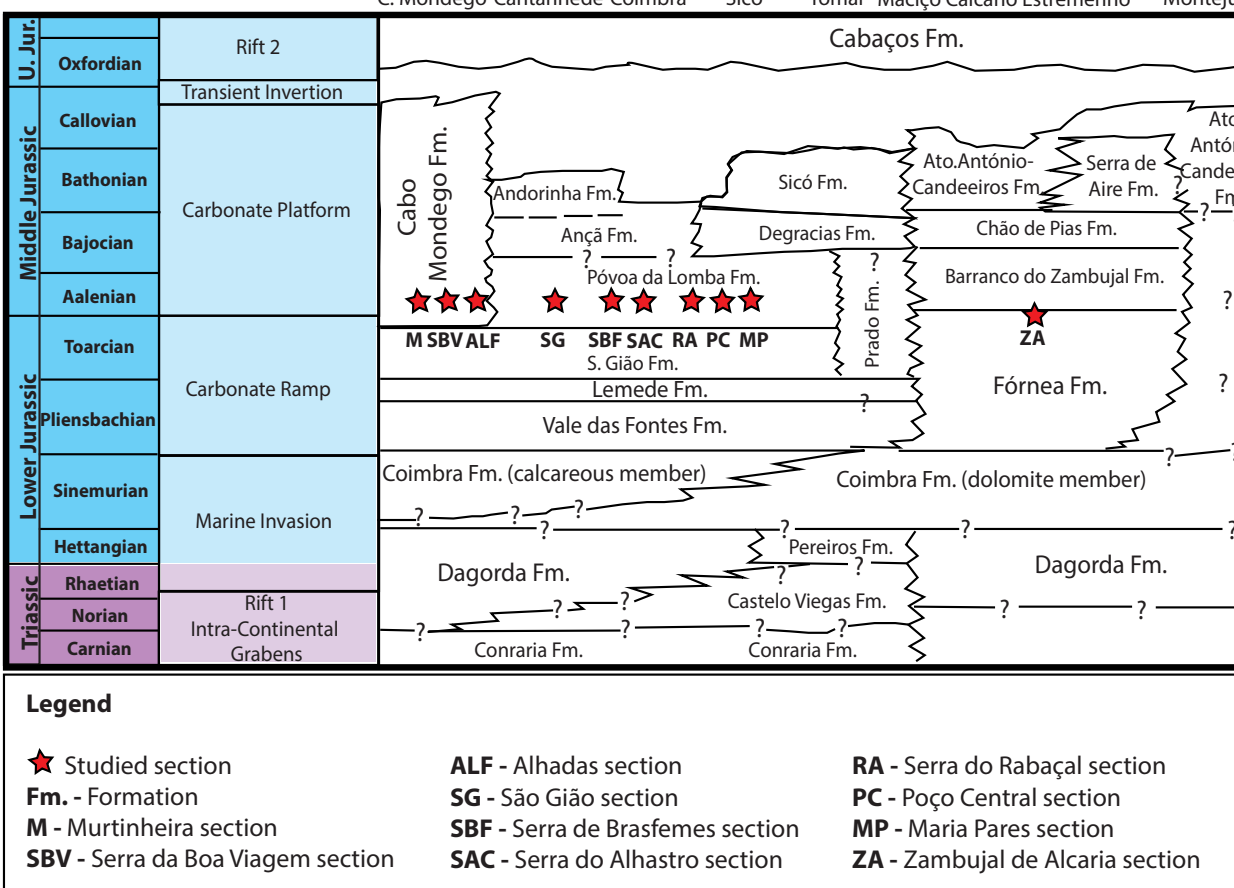

Figure 2. Synthetic lithostratigraphic chart for the upper Triassic and lower and middle Jurassic of the Lusitanian Basin, showing the position of the sections referred in this work (modified after Azerêdo et al., 2003; Pena dos Reis and Pimentel, 2014).

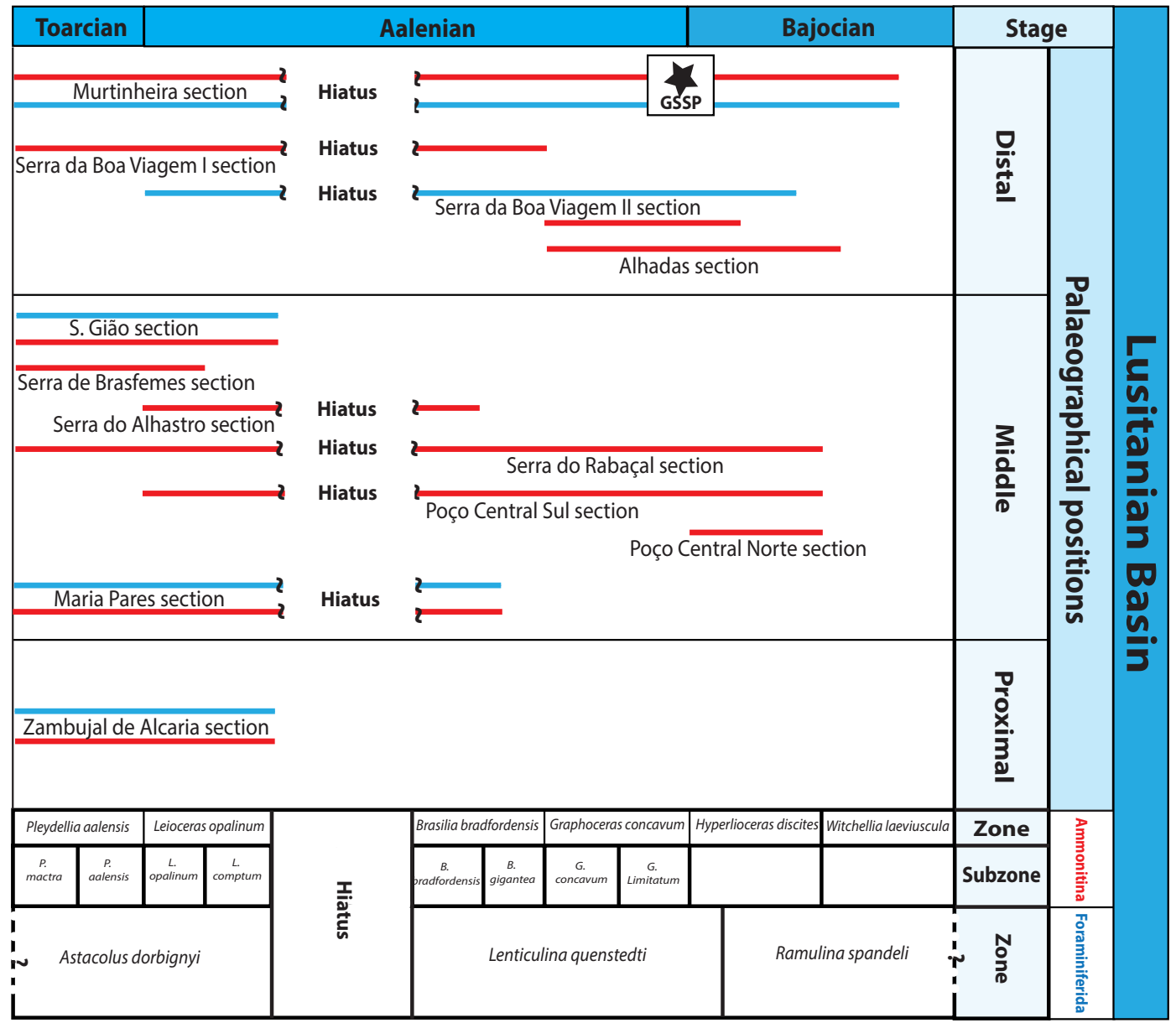

Figure 3. Paleogeographic location and stratigraphic range of the studied sections. Vertical lines represent sections where the ammonite (red) and foraminiferal (blue) record have been analyzed. 
The base of the Aalenian overlaps the Upper Toarcian sediments, where the Pleydellia aalensis Zone (integrating the P. mactra and the $P$. aalensis subzones) has been recognized. Its ammonite record is quite abundant, including different species of Cotteswoldia $-C$. costulata (Zieten), C. egena Buckman, C. limatula Buckman, $C$. paucicostata Buckman - distributed throughout both subzones. The index-fossil Pleydellia mactra (Dumortier) of the Pleydellia mactra Subzone is rare, but $P$. subcompta Branco (Fig. 4.1) and P. fluens (Buckman) are frequently found; $P$. aalensis (Zieten), $P$. comata (Buckman), P. folleata (Buckman) and P. lotharingica (Branco) occur at the Pleydellia aalensis Subzone, and persist at the base of the Aalenian, where they coexist with the first Leioceratinae. These ammonite taxa of Northwestern European affinities are associated with taxa having Mediterranean affinities such as Catulloceras, Vacekia - V. striata Henriques, V. sourensis (Perrot) - and Tmetoceras scissum (Benecke).

The Lower Aalenian is represented by taxa of the Leioceras opalinum Zone, which includes the L. opalinum and the L. comptum subzones (Figs. 4.2-4.6). The Lower - Middle Jurassic boundary is particularly well represented at the expanded section of São Gião, located in the Northern sector of the Lusitanian Basin (UTM coordinates: $40818012.630 \mathrm{~m} \mathrm{~N} ; 8837017.580 \mathrm{~m} \mathrm{~W}$; altitude: 100 $\mathrm{m})$, and described in detail by Henriques (1992) and Henriques and Canales (2013). Besides the index-fossil Leioceras opalinum (Reinecke), the Leioceras opalinum Subzone (Fig. 4.2) also includes Cypholioceras representatives - C. opaliniforme (Buckman) and $C$. lineatum (Buckman) - associated with Tmetoceras, Vacekia and Czerneyiceras representatives. The Leioceras comptum Subzone (Figs. 4.3-4.6) is characterized by the occurrence of the ribbed Cypholioceras comptum (Reinecke) and Leioceras costosum (Quenstedt), which coexist with the striate C. opaliniforme (Buckman), C. lineatum (Buckman) and L. opalinum (Reinecke), besides Vacekia striata Henriques and Tmetoceras scissum (Benecke), which may be quite abundant.

The Middle Aalenian is only recorded in its uppermost part, represented by the Brasilia bradfordensis Zone, consisting of the $B$. bradfordensis and the B. gigantea subzones (Figs. 4.7-4.8). Among all the biostratigraphic units recognized in the basin, this biozone is the poorest in terms of representativeness of the ammonite record; the Murtinheira section described in detail by Henriques (1992) and Canales and Henriques $(2008,2013)$ is the reference section for this time interval (UTM coordinates: $508382.26 \mathrm{~m} \mathrm{E} ; 4450156.07 \mathrm{~m} \mathrm{~N}$; altitude: $0 \mathrm{~m}$ ). The Brasilia bradfordensis Subzone (Fig. 4.7-4.8) is characterized by the occurrence of B. tutcheri (Buckman), B. umbilicata (Buckman), and Ludwigella rudis (Buckman) associated with the last Vacekia and Tmetoceras, and rare Bredyia, Planammatoceras and Erycites. Besides the species of Brasilia already present in the previous subzone, the Brasilia gigantea Subzone records representatives of B. gigantea (Buckman), B. similis (Buckman) and B. maggsi (Buckman), associated with the typically Mediterranean taxa Spinammatoceras - S. schindewolfi Linares and Sandoval and S. tenax (Vacek) - Malladaites and the earliest Fontannesia.

The Upper Aalenian is represented by the Graphoceras concavum Zone, including the G. concavum and the G. limitatum subzones. The Graphoceras concavum Subzone is characterized by the occurrence of representatives of the index-species associated with other species of the same genus: G. formosum (Buckman) and G. decorum Buckman. Ludwigella also occurs at its lower part, and the earliest Braunsina in its upper part $-B$. projecta Buckman and B. (?) compacta (Buckman).
The Mediterranean taxa Euaptetoceras klimakomphalum (Vacek) and Haplopleuroceras subspinatum (Buckman) are also represented in this subzone. The Graphoceras limitatum Subzone (Figs. 4.9-4.14) is recognized by the occurrence of its index-species (G. limitatum Buckman) associated with a wide variety of typical Northwestern European taxa, namely Graphoceratinae - G. formosum (Buckman), G. decorum Buckman, Braunsina contorta Buckman, B. aspera Buckman, B. projecta Buckman, B. aff. rotabilis (Buckman) and $B$. (?) compacta (Buckman) - together with typical Mediterranean ones such as Hammatoceratidae - Euaptetoceras klimakomphalum (Vacek) - and Erycitidae - Haplopleuroceras subspinatum (Buckman), H. eximium Gérard, Zurcheria tuberculata Fernández López, Mouterde and Rocha - and Otoitidae - Riccardiceras longalvum (Vacek).

The Hyperlioceras discites Zone (Figs. 4.15-4.17) is characterized by the first occurrence of an ammonite assemblage including Toxolioceras mundum (Buckman) and related species - Reynesella furcata (Buckman), Braunsina aspera Buckman and B. elegantula (Buckman). These Graphoceratidae, that also include several different species of Reynesella and Oedania, are replaced in the upper part of the biozone by Sonninniidae (Sonninia, Euhoploceras, Pelekodites and Nannoceras). Strigoceratidae, Bradfordiinae and Otoitidae also occur, but are comparatively less frequent.

The ammonite record of the Aalenian-Bajocian boundary is particularly well known at the Murtinheira section (Cape Mondego; UTM coordinates: $08241.90 \mathrm{~m} \mathrm{E}$; $4449943.29 \mathrm{~m} \mathrm{~N}$; altitude: $0 \mathrm{~m}$ ) as a result of the intensive research activities during the discussion that led to the definition of the Bajocian GSSP (Pavia and Enay, 1997 and references therein), the first stage boundary established for the Jurassic System by the IUGS. Reference literature regarding this issue includes Fernández López et al. (1988a, b), Henriques (1992), Henriques et al. (1988, 1994, 1996, 2010), Sandoval et al. (2000) and references therein.

\section{Foraminiferal-based biostratigraphic units}

The foraminiferal record of the Lower - Middle Jurassic transition in the Lusitanian Basin has been analyzed from the Upper Toarcian (Pleydellia aalensis Zone, P. mactra Subozone) to the Lower Bajocian (Hyperlioceras discites Zone) in five significant sections: Murtinheira and Serra da Boa Viagem II sections, located in the distal part of the platform; São Gião and Maria Pares sections, corresponding to the middle part of the platform; and Zambujal de Alcaria section, the most proximal of all of them (see Figs. 1 and 3).

A total of 110 assemblages, collected in marly or marly-limestone levels, were sampled and processed in the laboratory, using a classical methodology that allows 3D studies of the obtained specimens. More than 42,300 benthic foraminiferal specimens were recovered and classified (Canales and Henriques, 2008, 2013; Figueiredo and Guterres, 2012; Figueiredo et al., 2010; Henriques and Canales, 2013; Silva et al., 2015b). All the material is stored at the Laboratory of Sedimentary Geology and Fossil Record of the Department of Earth Sciences at the University of Coimbra (Portugal).

The studied assemblages are composed of typical taxa of the Jurassic marine platforms of the North Hemisphere, corresponding to the suborders Textulariina, Spirillinina, Miliolina, Lagenina, Robertinina and Rotaliina. Most of the studied assemblages are mainly 


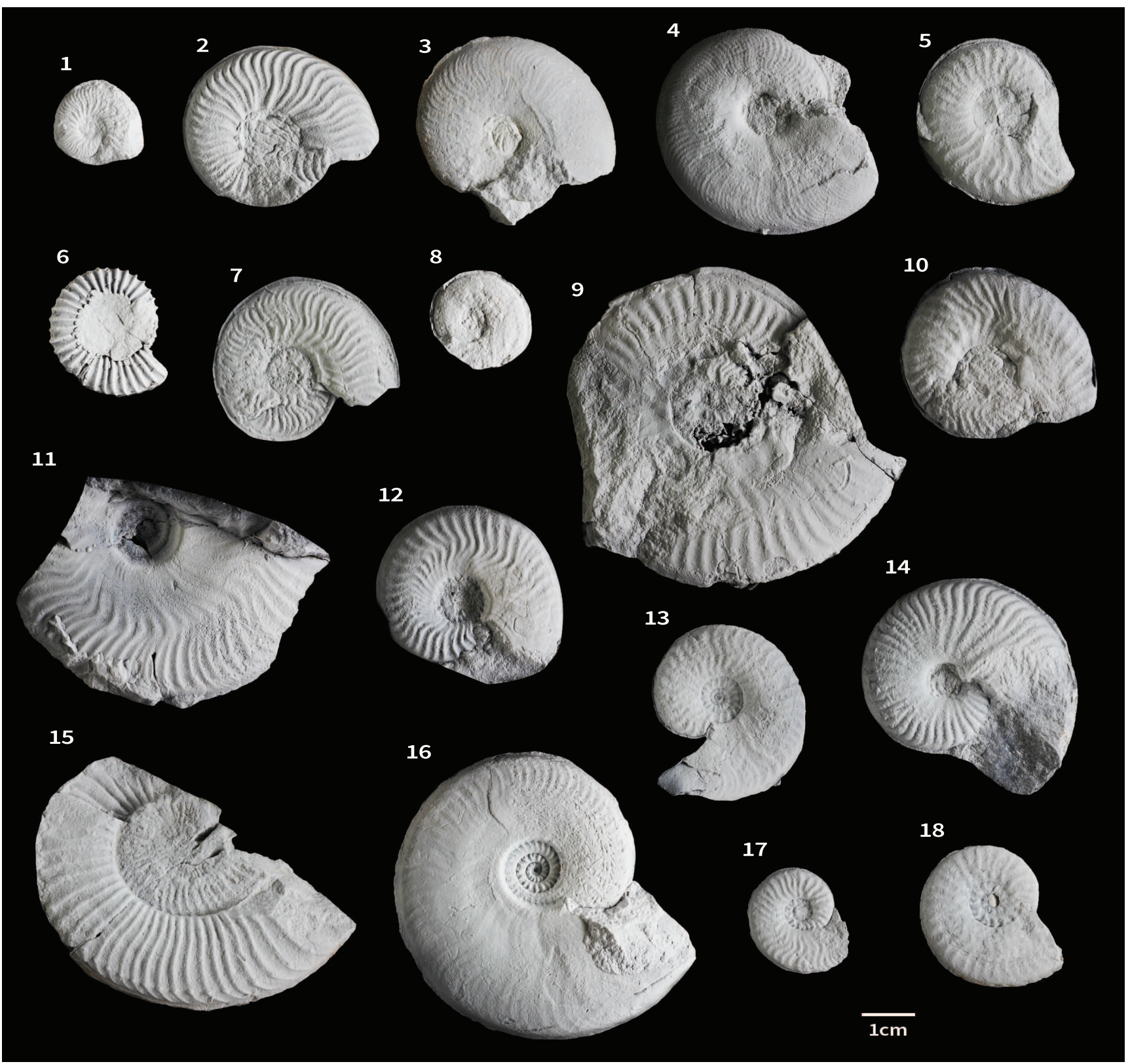

Figure 4. Selected ammonite specimens characterizing the biostratigraphic units recognized in the upper Toarcian-Aalenian-lower Bajocian of the Lusitanian Basin: 1. Pleydellia subcompta Branco, MP-10-3 from the Maria Pares section (Pleydellia aalensis Zone; P. mactra Subzone); 2. Pleydellia aalensis (Zieten), MP-35-1 from the Maria Pares section (Leioceras opalinum Zone; L. opalinum Subzone); 3. Leioceras opalinum (Reinecke), MP-47H3 from the Maria Pares section (Leioceras opalinum Zone; L. comptum Subzone); 4. Leioceras opalinum (Reinecke), MP-47I-18 from the Maria Pares section (Leioceras opalinum Zone; L. comptum Subzone); 5. Leioceras costosum (Quenstedt), SG-61-3 from the São Gião section (Leioceras opalinum Zone; L. comptum Subzone); 6. Tmetoceras scissum (Benecke), M-95-10 from the Murtinheira section (Leioceras opalinum Zone; L. comptum Subzone); 7. Brasilia tutcheri (Buckman), M-129-50 from the Murtinheira section (Brasilia bradfordensis Zone; B. bradfordensis Subzone); 8. Vacekia stephensi (Buckman), ZA-94-2 from the Zambujal de Alcaria section (Brasilia bradfordensis Zone; B. bradfordensis Subzone); 9. Ludwigella rudis (Buckman), M-129-60 from the Murtinheira section (Brasilia bradfordensis Zone; B. bradfordensis Subzone); 10. Graphoceras limitatum Buckman, M-284-1 from the Murtinheira section (Graphoceras concavum Zone; G. limitatum Subzone); 11. Graphoceras decorum Buckman, MP-153-1 from the Maria Pares section (Graphoceras concavum Zone; G. limitatum Subzone); 12. Braunsina (?) compacta (Buckman), M-284-3 from the Murtinheira section (Graphoceras concavum Zone; G. limitatum Subzone); 13. Reynesella furcata (Buckman), SBVII141-7 from the Serra da Boa Viagem II section (Graphoceras concavum Zone; G. limitatum Subzone); 14. Euaptetoceras klimakomphalum (Vacek), M-294-4 from the Murtinheira section (Graphoceras concavum Zone; G. limitatum Subzone); 15. Haplopleuroceras mundum Buckman, MP-134 from the Maria Pares section (Graphoceras concavum Zone; G. limitatum Subzone); 16. Toxolioceras mundum (Buckman), SBVII-141-6 from the Serra da Boa Viagem II section (Hyperlioceras discites Zone); 17. Braunsina aspera Buckman, SBVII137-6 (Hyperlioceras discites Zone); 18. Braunsina contorta Buckman, SBVII-139-23 from the Serra da Boa Viagem II section (Hyperlioceras discites Zone). 
constituted by representatives of the Lagenina Suborder. Textulariina, Spirillinina and Miliolina show high abundance in some paleoenvironmental conditions, whereas representatives of the surborders Robertinina and Rotaliina are minor constituents of the assemblages (Canales and Henriques, 2008, 2013; Canales et al., 2010, 2014; Figueiredo et al., 2010; Henriques and Canales, 2013; Henriques et al., 2010; Silva et al., 2014, 2015b).

With the aim of supporting accurate biostratigraphical and paleoecological interpretations, specimens were analyzed from a taphonomical point of view, and processes such as bioerosion, abrasion, fragmentation, recrystallization, partial or total dissolution of the shells, sedimentary infillings and distortion were recognized in isolated specimens. However, no evidence of significant alteration in the composition of the original assemblages was detected (Canales et al., 2014; Figueiredo and Guterres, 2012; Henriques and Canales, 2013; Silva et al., 2014).

From a biostratigraphical point of view, the studied foraminiferal record has enabled the establishment of a zonal scale accurately calibrated with the ammonite-based biostratigraphy. The three proposed biozones (Fig. 3), namely Astacolus dorbignyi Zone, Lenticulina quenstedti Zone and Ramulina spandeli Zone, are based on the First Appearance Datum (FAD) of abundant and easily recognizable species, thus corresponding to interval zones (Murphy and Salvador, 1999).

The Astacolus dorbigny Zone was firstly proposed by Canales (2001) for the Basque-Cantabrian Basin (Northern Spain). Its lower boundary still remains undefined, but work in progress suggests that the FAD of Astacolus dorbignyi (Roemer) (Fig. 5.1) may be located in the Pleydellia mactra Subzone (Upper Toarcian). Its upper boundary coincides with the FAD of Lenticulina quenstedti (Gümbel) the following index-species, located at the base of the Brasilia gigantea Subzone. This biozone has been recognized in all the studied sections of the Lusitanian Basin. Foraminiferal assemblages from this biozone are characterized by the gradual replacement of some Lower Jurassic foraminiferal taxa by typical Middle Jurassic ones.

The Lenticulina quenstedti Zone ranges from the base of the Brasilia gigantea Subzone to the lower part of the Hyperlioceras discites Zone. It was firstly proposed by Canales (2001) for the Basque-Cantabrian Basin, where its upper boundary was undefined, and it is based on the FAD of Lenticulina quenstedti (Gümbel) (Fig. 5.2). Studies carried out in the Lusitanian Basin (Canales and Henriques, 2013) allowed the establishment of its upper boundary at the base of the Bajocian. Foraminiferal assemblages are usually abundant and diverse throughout this biostratigraphic unit, but a strong

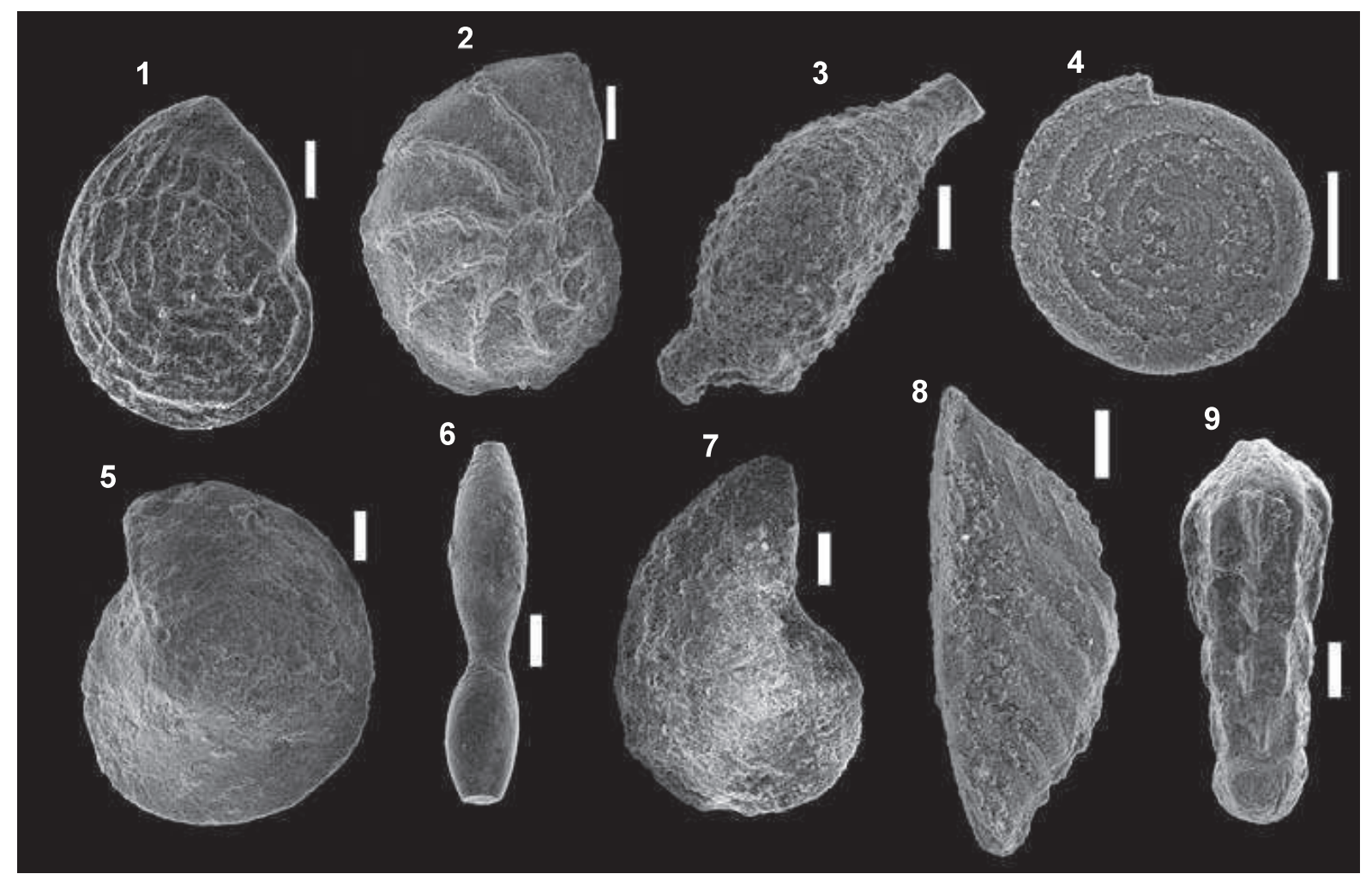

Figure 5. Selected benthic foraminifera specimens characterizing the biostratigraphic units recognized in the upper Toarcian-Aalenianlower Bajocian of the Lusitanian Basin: 1. Astacolus dorbignyi Roemer, MP-26-4-50 from the Maria Pares section (Pleydellia aalensis Zone; P. aalensis Subzone); 2. Lenticulina quenstedti (Gümbel), M-291.1327 from the Murtinheira section (Graphoceras concavum Zone; G. limitatum Subzone); 3. Ramulina spandeli Paalzow, SBVII-177-1-43 from the Serra da Boa Viagem II section (Hyperlioceras discites Zone); 4. Spirillina numismalis Terquem and Berthelin, SG-54-55-215 from the São Gião section (Leioceras opalinum Zone; L. opalinum Subzone); 5. Lenticulina muensteri (Roemer), M-273.1326 from the Murtinheira section (Graphoceras concavum Zone; G. concavum Subzone); 6. Prodentalina $c f$. fragilis (Terquem) SG-64-122-282 from the São Gião section (Leioceras opalinum Zone; L. comptum Subzone); 7. Lenticulina bochardi (Terquem), ZB-18-15-15 from the Zambujal de Alcaria section (Pleydellia aalensis Zone; P. aalensis Subzone); 8. Citharina colliezi (Terquem), SG-78-93-253 from the São Gião section (Leioceras opalinum Zone; L. comptum Subzone); 9. Nodosaria pulchra (Franke) MP-47-21-24 from the Maria Pares section (Leioceras opalinum Zone; L. opalinum Subzone). Scale bars: $100 \mu \mathrm{m}$. 
decrease in abundance and diversity was detected at the Upper Aalenian - Lower Bajocian transition.

The Ramulina spandeli Zone was proposed for the Lusitanian Basin (Canales and Henriques, 2013). Its lower boundary coincides with the FAD of Ramulina spandeli Paalzow (Fig. 5.3) in the lower part of the Hyperlioceras discites Zone, whereas its upper boundary is still undefined. Foraminiferal assemblages are characterized by a recovery in abundance and diversity and are constituted by typical Middle Jurassic taxa.

Several bioevents based on the first or last appearances of a taxon, significant changes in the abundance of one or several taxa or noticeable changes in diversity of the assemblages recorded in the studied sections were also recognized (Canales and Henriques, 2008, 2013; Figueiredo and Guterres, 2012; Figueiredo et al., 2010, 2014; Henriques and Canales, 2013; Henriques et al., 2010; Silva et al., 2014, 2015b). Most of these bioevents have local application, but some of them have been detected not only in several sections of the Lusitanian Basin, but in other basins located around the Iberian Plate, thus increasing its biostratigraphical and/or paleoecological value. Among bioevents with local value, it is noticeable the strong increase of the representatives of the Suborder Miliolina in the assemblages recorded in the Leioceras comptum Subzone of the expanded section of São Gião, located in the middle part of the platform (Figs. 1 and 3). This bioevent, which is coeval with an increase in the occurrence of Mediterranean taxa in the ammonite assemblages, allowed Henriques and Canales (2013) to question the paleogeographic range of the so-called "Comptum cooling event" previously proposed for the Early Aalenian (Sandoval et al., 2008; Gómez et al., 2009; Price, 2010). On the other hand, the strong decrease in foraminiferal abundance and diversity recorded in the assemblages of the Aalenian -Bajocian transition represents a widespread bioevent, as it has been recognized in other Iberian and European basins (Canales, 2001; Morris, 1982; Morris and Coleman, 1989; Ruban and Tyszka, 2005).

The study of the foraminiferal record from different positions within the Lusitanian Basin based on an innovative multivariate analysis of the recovered material from the Upper Toarcian - Lower Aalenian designed and applied by Canales et al. (2014) has enabled paleoecological interpretations supported by qualitative and quantitative data. The obtained results pointed out that the taxonomical composition of the assemblages is quite similar throughout the studied stratigraphic interval (only $5 \%$ of difference), whereas taxonomical differences between sections located within the basin are higher $(22 \%$ difference). Paleoecological preferences of some species were mathematically demonstrated, i.e. Spirillina numismalis Terquem and Berthelin (Fig. 5.4) and Lenticulina muensteri (Roemer) (Fig. 5.5) are typical of the outer part of the platform, Prodentalina cf. fragilis (Terquem) (Fig. 5.6), P. propinqua (Terquem), P. torta (Terquem), Lenticulina bochardi (Terquem) (Fig. 5.7) and Citharina colliezi (Terquem) (Fig. 5.8) are more abundant in the middle part of the platform and, finally, Nodosaria pulchra (Franke) (Fig. 5.9) preferred the inner part of the platform. The recognition of these preferences can be very useful in the analysis of core samples, thus assisting in the interpretation of depositional environments of Jurassic onshore and offshore basins of the North Hemisphere.

\section{Conclusion}

The Aalenian of the Lusitanian Basin (Western Iberian Margin) is particularly well represented in several outcrops located in
Central Portugal, corresponding to distal, middle and proximal paleogeographic positions within a carbonate platform. During the last two decades detailed sampling for the study of the ammonite and foraminifera record has been carried out in ten reference sections, aiming at establishing an accurate biostratigraphic framework based on the co-occurrence of these two fossil groups.

The biostratigraphic units based on the ammonite record has enabled the recognition of the Leioceras opalinum Zone (including the L. opalinum and the L. comptum subzones) corresponding to the Lower Aalenian, the Brasilia bradfordensis Zone (including the $B$. bradfordensis and the $B$. gigantea subzones) corresponding to the upper part of the Middle Aalenian, and the Graphoceras concavum Zone (including the G. concavum and the G. limitatum subzones) corresponding to the Upper Aalenian. They can be recognized in coeval sections around the Iberian Plate, namely at the BasqueCantabrian Basin, and at the Betic and Iberian Cordilleras (Henriques et al., 1996, Sandoval et al., 2001, Gómez et al., 2009, Henriques et al., 2014 and references therein). P. aalensis and L. opalinum zones have also been recognized in the West Tethys Toarcian - Aalenian transition of the Northern Apennines (Cresta et al., 1995).

The biostratigraphic units based on the foraminiferal record includes the Astacolus dorbignyi Zone, ranging, at least, from the $P$. aalensis Zone (Upper Toarcian) to the Leioceras opalinum Zone (Lower Aalenian), the Lenticulina quenstedti Zone, ranging from the Brasilia bradfordensis Zone (Middle Aalenian) to the lower part of the Hyperlioceras discites Zone (Lower Bajocian), and the Ramulina spandeli Zone, beginning at the Hyperlioceras discites Zone but with the upper limit still undefined. The three biostratigraphic units can be recognized at the Basque-Cantabrian Basin and at the Iberian Cordillera, and the first two are also recognized at the Betic Cordillera (Henriques et al. 2014, Silva et al., 2015a). Several bioevents have also been recognized based on the First Appearance Datum, Last Appearance Datum and noticeable changes in assemblages' richness or in the relative abundance of some taxa in the foraminiferal assemblages. The decrease in abundance and diversity of foraminiferal assemblages recorded at the Aalenian - Bajocian transition, identified in all the studied sections was recognized not only in the context of Iberia, but also in other northern hemisphere basins (Morris and Coleman, 1989; Ruban and Tyszka, 2005).

The integration of these two biostratigraphical scales, one based on the best fossil group to assign an Aalenian age to marine sediments, and the other based on foraminifera, represents an important contribution towards a better calibration of the biostratigraphic scale for the Aalenian on the basis of macro- and microfossil groups. Moreover, the benthic foraminifera-based biostratigraphic units now described, as well as the identified bioevents, accurately calibrated with the ammonite-based biostratigraphy, can be of great relevance to determinate both the age and depositional environment assigned to core samples from the shallow and deep offshore basins of the Western Iberian Margin and from other sedimentary basins of Jurassic age.

\section{Acknowledgements}

This work was supported by FEDER funds through the Competitiveness Factors Operational Programme - COMPETE and national funds by FCT in the frame of the UID/Multi00073/2013 project. The study is a contribution for the Projects CGL2011-23947 and CGL2011-25894 (Ministerio de Ciencia e Innovación, Spain) 
and for the Grupo de Investigación UCM 910431 (Complutense University, Madrid, Spain). The laboratory work was supported by the Consórcio Petrobras-Galp-Partex of Portugal. The authors are grateful to Carlos Recio and Sérgio Pinheiro for their assistance with the photographic treatmentof the ammonite specimens and to the Centro Nacional de Microscopía Electrónica for the SEM photographs of foraminifer specimens, both of the Complutense University of Madrid (Spain). The authors are deeply grateful to Dr. José Sandoval and to Dr. Giulio Pavia for the careful revision of the manuscript.

\section{References}

Azerêdo, A.C., Duarte, L.V., Henriques, M.H. and Manuppella, G., 2003, Da dinâmica continental no Triásico aos mares do Jurássico Inferior e Médio: Cadernos de Geologia de Portugal, Instituto Geológico e Mineiro, Lisboa, 43 p. (ISBN: 972-98469-9-5).

Canales, M.L., 2001, Los foraminíferos del Aaleniense (Jurásico Medio) en la Cuenca Vasco-Cantábrica ( $\mathrm{N}$ de España): Revista Española de Micropaleontología, v. 33, pp. 253-438.

Canales, M.L. and Henriques, M.H., 2008, Foraminifera from the Aalenian and the Bajocian GSSP (Middle Jurassic) of Murtinheira section (Cabo Mondego, West Portugal): Biostratigraphy and paleoenvironmental implications: Marine Micropaleontology, v. 67, no 1-2, pp. 155-179.

Canales, M.L. and Henriques, M.H., 2013, Foraminiferal assemblages from the Bajocian Global Stratotype Section and Point (Cape Mondego, Portugal): Journal of Foraminiferal Research, v. 43, no 2, pp. 182-206.

Canales, M.L., García-Baquero, G., Henriques, M.H. and Figueiredo, V.L., 2014, Palaeoecological distribution pattern of Early-Middle Jurassic benthic foraminifera in the Lusitanian Basin (Portugal) based on multivariate analysis: Palaeogeography, Palaeoclimatology, Palaeoecology, v. 410, pp. 14-26.

Canales, M.L., Henriques, M.H., Figueiredo, V.L. and Guterres, H., 2010, Foraminifera from the Lower-Middle Jurassic of the Lusitanian Basin (Portugal) - biostratigraphic and palaeoecological significance. In: Pena dos Reis, R. and Pimentel, N., eds., Rediscovering the Atlantic: new ideas for an old sea: II Central \& North Atlantic Conjugate Margins Conference Lisbon 2010, pp. 42-46 (ISBN: 978-989-96923-3-6).

Cresta, S., Basilici, G., Bussolet, A., Comas, M.J., Elmi, S., Fernández López, S., Ferreti, A., Goy, A., Henriques, M.H., Kälin, O., Jiménez, A., Martínez, G., Sandoval, J., Ureta, S. and Venturi, F.,1995, Relazione sul workshop Paleontologia e biostratigrafia dei sedimenti ammonitiferi ToarcianoBajociani in successioni di alto morfostrutturale dell'Appennino UmbroMarchigiano: 1'area di Monte Nerone. Correlazioni con altre regioni della Tetide occidentale (Piobbico, 2-14 agosto 1993), Bolletino del Servizio Geologico d'Italia, v. CXII (1993), pp. 129-139.

Fernández López, S., Henriques, M.H., Linares, A., Sandoval, J. and Ureta, M.S., 1999a, Aalenian Tmetoceras (Ammonoidea) from Iberia. Taxonomy, habitats, and evolution. In: Olóriz, F. and Rodríguez-Tovar F.J., eds., Advancing Research on Living and Fossil Cephalopods: Kluwer Academic/Plenum Publishers, pp. 91-108.

Fernández López, S., Henriques, M.H., Linares, A., Sandoval, J. and Ureta, M.S., 1999b, Aalenian Tmetoceras (Ammonoidea) from Iberia. Taphonomy and palaeobiogeography. In: Olóriz, F. and Rodríguez-Tovar F.J., eds., Advancing Research on Living and Fossil Cephalopods: Kluwer Academic/Plenum Publishers, pp. 395-417.

Fernández López, S., Henriques, M.H.P., Mouterde, R., Rocha, R. and Sadki, D., 1988a, Le Bajocien inférieur du Cap Mondego (Portugal). Essai de biozonation. In: Rocha, R.B. and Soares, A.F., eds., 2nd International Symposium on Jurassic Stratigraphy, Lisbon, v. 1, pp. 301-313.

Fernández López, S., Mouterde, R. and Rocha, R., 1988b, Les Zurcheria s. 1. (Ammonitina, Erycitidae) du Bajocien Inférieur du Cap Mondego (Portugal). In: Rocha, R.B. and Soares, A.F., eds., 2nd International Symposium on Jurassic Stratigraphy, Lisbon, v. 1, pp. 283-300.

Figueiredo, V., Canales, M.L. and Henriques, M.H., 2014, Foraminifera of the Toarcian-Aalenian boundary from the Lusitanian Basin (Portugal): a paleoecological analysis: Journal of Iberian Geology, v. 40, no. 3, pp. 431-450.

Figueiredo, V. and Guterres, H., 2012, Análise Quantitativa das Associações de Foraminíferos da Passagem Jurássico Inferior-Médio do Perfil de Maria Pares (Setor Norte da Bacia Lusitânica, Portugal) - Implicações Paleoecológicas. In: Lopes, F.C., Andrade, A.I., Henriques, M.H., FerreiraQuinta, M., Barata, M.T. and Pena dos Reis, R., eds., Para Conhecer a Terra, Memórias e Notícias de Geociências no Espaço Lusófono: Imprensa da Universidade de Coimbra/Coimbra Academic Press, pp. 151-159 (ISBN: 978-989-26-0511-1).

Figueiredo, V.L., Henriques, M.H. and Canales, M.L., 2010, Foraminíferos da Passagem Jurássico Inferior - Médio do Sector Central da Bacia Lusitânica: o Perfil de Zambujal de Alcaria: Boletim de Geociências da Petrobras, v. 19, pp. 207-234.

Gómez J.J., Canales, M.L., Ureta, S. and Goy, A., 2009, Palaeoclimatic and biotic changes during the Aalenian (Middle Jurassic) at the southern Laurasian Seaway (Basque-Cantabrian Basin, northern Spain): Palaeogeography, Palaeoclimatology, Palaeoecology, v. 275, pp. 14-27.

Henriques, M.H.P., 1992, Biostratigrafia e Paleontologia (Ammonoidea) do Aaleniano em Portugal (Sector Setentrional da Bacia Lusitaniana), Unpublished $\mathrm{PhD}$ thesis, Univ. Coimbra, 301p.

Henriques, M.H., 1995, Les faunes d'ammonites de l'Aalénien Portugais: composition et implications paleobiogéographiques: Geobios, $n^{\circ} 28$, Issue Suppl. 1, pp. 229-235.

Henriques, M.H.P., 2000, Aalenian of the Zambujal de Alcaria section (Central Lusitanian Basin, Portugal). In: Hall, R.L. and Smith, P. L., eds., Advances in Jurassic Research 2000: GeoResearch Forum 6, Transtec Pub., pp. 85-94.

Henriques, M.H. and Canales, M.L., 2013, Ammonite-benthic foraminifera turnovers across the Lower-Middle Jurassic transition in the Lusitanian Basin (Portugal): Geobios, v. 46, no. 5, pp. 395-408.

Henriques, M.H., Canales, M.L., Figueiredo, V., García-Frank, A., Hernández, L., Silva, S. and Ureta, S., 2014, Biostratigrafia integrada (Ammonoidea, Foraminiferida) da passagem Jurássico Inferior-Médio na Península Ibérica: resultados preliminares: Comunicações Geológicas, v. 101 (Especial I), LNEG, pp. 443-446.

Henriques, M.H., Canales, M.L., Neto, K. and Antunes, R.L., 2010, Day 1; Stop 1A - Cabo Mondego North. In: Pena dos Reis, R. and Pimentel, N., eds., Rediscovering the Atlantic: new ideas for an old sea: II Central \& North Atlantic Conjugate Margins Conference Lisbon 2010, pp. 9-15 (ISBN: 978-989-96923-3-6).

Henriques, M.H., Gardin, S., Gomes, C.R., Soares, A.F., Rocha, R.B., Marques, J.F., Lapa, M.R. and Montenegro, J.D., 1994, The AalenianBajocian boundary at Cabo Mondego (Portugal): Miscellanea del Servizio Geologico Nazionale, v. V, pp. 63-77.

Henriques, M.H., Linares, A., Sandoval, J. and Ureta, M.S., 1996, The Aalenian in the Iberia (Betic, Lusitanian and Iberian Basins). In: Riccardi, A.C., ed., Advances in Jurassic Research: GeoResearch Forum 1-2, Transtec Pub., pp. 139-150.

Henriques, M.H., Sadki, D. and Mouterde, R., 1988, Graphoceratidés (Ammonitina) de la base du Bajocien portugais. In: Rocha, R.B. and Soares, A.F., eds., 2nd International Symposium on Jurassic Stratigraphy, Lisbon, v. 1, pp. 243-254.

Morris, P.H., 1982, Distribution and palaeoecology of Middle Jurassic Foraminifera from the Lower Inferior Oolite of the Cotswolds: Palaeogeography, Palaeoclimatology, Palaeoecology, v. 37, pp. 319-347.

Morris, P.H., and Coleman, B.E., 1989, The Aalenian to Callovian (Middle Jurassic). In: Jenkins, D.G. and Murray, J.W., eds., Stratigraphical Atlas of Fossil Foraminifera, $2^{\text {nd }}$ ed.: Ellis Horwood Ltd, pp. 189-236.

Murphy, M.A. and Salvador, A., eds., 1999, International Stratigraphic Guide - An abridged version, International Subcommission on Stratigraphic Classification of IUGS International Commission on Stratigraphy. <http:/ /www.stratigraphy.org/bak/guide/abguid.htm> (retrieved May 2015).

Pavia, G. and Enay, R., 1997, Definition of the Aalenian-Bajocian stage boundary: Episodes, v. 20, pp. 16-22.

Pena dos Reis, R. and Pimentel, N., 2010, A Bacia Lusitânica (Portugal): 
análise estratigráfica e evolução geodinâmica: Boletim de Geociências da Petrobras, v. 19, pp. 23-51.

Pena dos Reis, R. and Pimentel, N., 2014, Analysis of the Petroleum Systems of the Lusitanian Basin (Western Iberian Margin) — A Tool for Deep Offshore Exploration. In: Pindell, J., Horn, B., Rosen, N., Weimer, P., Dinkleman, M., Lowrie, A., Fillon, R., Granath, J. and Kennan, L., eds., Sedimentary Basins, Origin, Depositional Histories, and Petroleum Systems, 33rd GCSSEPM Foundation Bob F. Perkins: Research Conference, pp. 228-255.

Pimentel, N., Pena dos Reis, R. and Bueno, G., 2010, Guia de Campo da Bacia Lusitânica, Portugal: Boletim de Geociências da Petrobras, v. 19, pp. 251-275.

Price, G.D., 2010, Carbon-isotope stratigraphy and temperature change during the Early-Middle Jurassic (Toarcian-Aalenian), Raasey, Scotland, UK: Palaeogeography, Palaeoclimatology, Palaeoecology, v. 285, pp. 255-263.

Ruban, D.A. and Tyszka, J., 2005, Diversity dynamics and mass extinctions of the Early-Middle Jurassic foraminifera: a record from the Northwestern Caucasus: Palaeogeography, Palaeoclimatology, Palaeoecology, v. 222, pp. 329-343.

Sandoval, J., Henriques, M.H., Chandler, R. and Ureta, S., 2012, Latest Toarcian-earliest Bajocian (Jurassic) Grammoceratinae (Hildoceratidae, Ammonitina) of the western Tethys: their palaeobiogeographic and phylogenetic significance: Geobios, v. 45, pp. 109-119.

Sandoval, J., Henriques, M.H., Ureta, S., Goy, A. and Rivas, P., 2001, The Lias/Dogger boundary in Iberia: Betic and Iberian cordilleras and

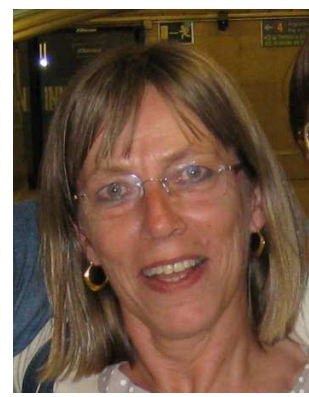

Maria Helena Henriques is Professor at the Earth Sciences Department of the Faculty of Sciences and Technology of the University of Coimbra (Portugal) and Researcher of the Geosciences Centre of the same University. Graduated in Geology and in Journalism, PhD and $S c D$ in Palaeontology and Stratigraphy by the University of Coimbra, she is the Convenor of the Aalenian Working Group of the International Subcommission on Jurassic Stratigraphy (ICS, IUGS) and integrates the Portuguese Committee for the International Geoscience Programme (IGCP).

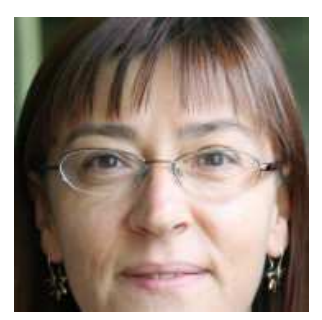

María Luisa Canales is Professor at the Department of Paleontology of the Faculty of Geological Sciences of the University Complutense of Madrid (Spain) and Collaborator Member of the Geosciences Centre of the University of Coimbra (Portugal). Her main scientific areas of research include micropalaeontology of Jurassic benthic foraminifera and high resolution biostratigraphy of Iberian basins, mainly regarding the upper Toarcian-Aalenian-lower Bajocian interval.
Lusitanian basin: Bulletin de la Société Géologique de France, v. 172, no. 4, pp. 387-395.

Sandoval, J., Linares, A. and Henriques, M.H., 2000, The Middle Jurassic genus Riccardiceras (Otoitidae, Ammonitina) in the Westernmost Tethys: Betic Cordillera and Lusitanian Basin: Revue de Paléobiologie, vol. spéc. 8, pp. 29-44.

Sandoval, J., O'Dogherty, L., Aguado, R., Bartolini, A., Bruchez, S. and Bill, M., 2008, Aalenian carbon-isotope stratigraphy: calibration with ammonite, radiolarian and nannofossil events in the Western Tethys: Palaeogeography, Palaeoclimatology, Palaeoecology, v. 267, pp. 115-137.

Silva, S., Henriques, M.H. and Canales, M.L., 2014, Análise paleoecológica baseada em foraminíferos da passagem Aaleniano-Bajociano (Jurássico Médio) do perfil da Serra da Boa Viagem II: Comunicações Geológicas, v. 101 (Especial I), LNEG, pp. 573-576.

Silva, S.C., Canales, M.L., Sandoval J. and Henriques, M.H., 2015a, Benthic foraminiferal assemblages across the Aalenian-Bajocian (Middle Jurassic) in the Barranco de Agua Larga section (Betic Cordillera, Spain) biostratigraphic considerations (abs.): AAPG European \& Regional Conference \& Exhibition 2015 "Tethys-Atlantic Interaction Along the European-Iberian-African Plate Boundaries" Abstracts, pp. 83-84.

Silva, S., Henriques, M.H. and Canales, M.L., 2015b, High resolution ammonite-benthic foraminiferal biostratigraphy across the AalenianBajocian boundary in the Lusitanian Basin (Portugal): Geological Journal, v. 50 , no. 4 , pp. $477-496$.

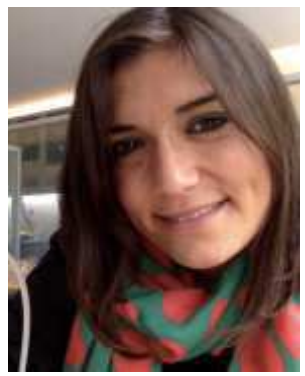

Sílvia Clara da Silva graduated in Geology and MSc in Geosciences (Oil Geology) at the University of Coimbra (Portugal). As Collaborator Member of the Geosciences Centre of the University of Coimbra, she develops current research in micropalaeontology of Jurassic benthic foraminifera and high resolution biostratigraphy of Iberian basins, mainly concerning the Aalenian-Bajocian transition.

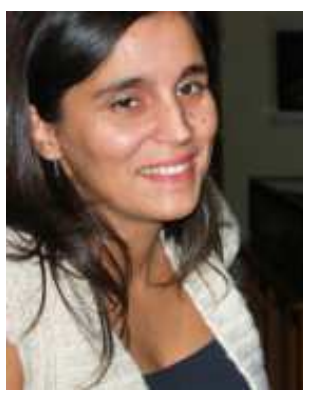

Vera Figueiredo graduated in Geology and $\mathrm{MsC}$ in Geosciences (Oil Geology) at the University of Coimbra (Portugal). As Collaborator Member of the Geosciences Centre of the University of Coimbra, she authored and co-authored several papers and presentations about micropalaeontology of Jurassic benthic foraminifera and high resolution biostratigraphy of Iberian basins, mainly regarding the ToarcianAalenian transition, which is her current research interest. 